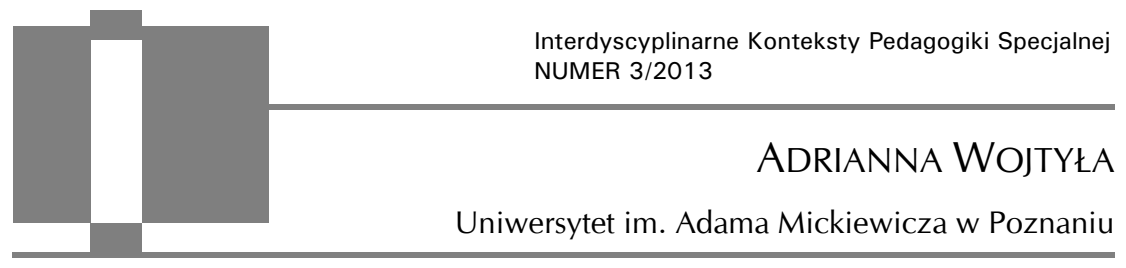

\title{
(Nie)normalność w społecznym zwierciadle. Opresyjne wzory, podziały oraz projekty cielesności jako kontekst doświadczenia kobiet z widoczną niepełnosprawnością
}

\begin{abstract}
Wojtyła Adrianna, (Ab)normality in the mirror of the society. Oppressive models, divisions and projects of corporeality as a context for the experience of women with visible disabilities [(Nie)normalność w społecznym zwierciadle. Opresyjne wzory, podziały oraz projekty cielesności jako kontekst doświadczenia kobiet z widoczną niepełnosprawnością]. Interdyscyplinarne Konteksty Pedagogiki Specjalnej, nr 3, Poznań 2013. Pp. 101-124. Adam Mickiewicz University Press. ISBN 978-83-232-2721-2. ISSN 2300-391X.
\end{abstract}

The article discusses the perception of physical otherness. The author compares theoretical knowledge regarding the mechanisms according to which stereotypes function with the empirical approach to the concept of femininity. The content of the article is intended to provoke reflection on the condition of value system in the society and to show the complexity behind the gender-related aspects of self-identity. The core of this analysis is to answer the question: 'What lays the basis for the sense of femininity?'; especially for disabled people, a group which seems to somehow diverge from commonly accepted norms. Research findings quoted In the article allow to approach the problem from a different perspective in order to rediscover the power of femininity which comes primarly from non-physical traits. The author's intention is to show what criteria of judgement are used in the contemporary society, as well as to emphasize the importance of the often ignored phenomenon discussed in the article.

KEY WORDS: disability, social norms, stigma, stereotypes, woman in popular culture, definitions of femininity 


\section{Uwagi wprowadzające}

Uwikłanie w kontekst ponowoczesności ${ }^{1}$ narzuca standardy implikujące zmiany w tożsamości jednostki oraz określony sposób myślenia o wybranych zjawiskach życia zbiorowego. Próba mentalnej separacji od systemu znaczeń wypracowanych w tradycji danej kultury stanowi dla członka wspólnoty ogromne wyzwanie. Sukcesywnie, z większą lub mniejszą świadomością, stajemy się "strażnikami” społecznie zdefiniowanego pojęcia normalności². Co za tym idzie, codziennie bezkrytycznie osądzamy fakty, których zrozumienie wymagałoby jednak głębszej refleksji. Rezygnacja z pochopnie dokonywanych ocen przychodzi z trudem, zakładając, że w ogóle pojawia się jakakolwiek chęć przekształcenia istniejących już schematów myślenia czy działania - uruchamianych podczas interakcji.

Formą uproszczenia otaczającej rzeczywistości są stereotypy. Znajomość licznych psychospołecznych teorii uświadamia różnorodność czynników przyczyniających się do tworzenia tego mechanizmu. Po pierwsze, ludzki umysł przejawia skłonność do minimalizacji energii wydatkowanej na poznanie zjawisk czy osób ${ }^{3}$ Na podstawie tak zwanych cech kategorialnych, a więc wyrazistych właściwości obiektu, postrzegający automatycznie uruchamia nabyte schematy myślowe, po czym dokonuje rozpoznania umożliwiającego mu szybką i stosunkowo adekwatną reakcję. Błyskawiczne dokonanie orientacji w sytuacji powoduje, że obserwowana osoba zostaje bez większego namysłu zakwalifikowana do określonej kategorii społecznej, co najczęściej niesie dla niej negatywne skut-

1 Por. Z. Bauman, Ponowoczesność jako źródło cierpień, Wydawnictwo Sic!, Warszawa 2011.

2 Fragment ten koresponduje z treścią publikacji Ervinga Goffmana pt. Piętno. Rozważania o zranionej tożsamości (Gdańskie Wydawnictwo Psychologiczne, Gdańsk 2007). Autor tworzy definicję pojęcia Umwelt oznaczającego według niego „lokalny świat sensów kulturowych, kodów komunikacyjnych, stereotypów reakcji na specyficzne sygnały innych uczestników społecznych sytuacji".

${ }^{3}$ Fiske, Taylor, 1991, za: E. Aronson, Człowiek - istota społeczna, Wydawnictwo Naukowe PWN, Warszawa 2004, s. 116-117. 
$\mathrm{ki}^{4}$. Należy podkreślić, że stereotypowe myślenie w znaczący sposób zniekształca procesy kognitywne, takie jak: percepcja, uwaga, interpretacja, przechowywanie informacji społecznych, ocenianie i reakcje behawioralne ${ }^{5}$. Ściślej ujmując, umysł mimowolnie dąży do takiej organizacji napływających do niego komunikatów, która potwierdzałaby treść istniejącego już wzorca. Ubocznym skutkiem motywacji do osiągnięcia takowej zgodności jest fakt, iż postrzegana osoba zostaje pozbawiona większości cech indywidualnych. Mechanizm ten ma silny związek z efektem homogeniczności oraz zjawiskiem faworyzowania grupy własnej, które głoszą, że człowiek ma tendencję do dzielenia osób $\mathrm{z}$ otoczenia pod względem kryterium przynależności do grupy „my” lub „oni”. Oznacza to, iż członek obcej zbiorowości podlega uproszczonej (niekorzystnej dla niego) ocenie, szczególnie wtedy, kiedy zostaje wobec niego użyta etykieta językowa. Nazwanie kogoś „cyganem” czy „niepełnosprawnym” wywołuje najczęściej szerokie spektrum skojarzeń, za sprawą których ignoruje się rzeczywiste właściwości człowieka, usilnie doszukując się w nim cech specyficznych dla utożsamianej z nim grupy ${ }^{6}$. Subiektywizm oceny wzmacnia dodatkowo inne zjawisko - zwane pozorna (iluzoryczna) korelacja. Jednostka postrzegająca zauważa obiektywnie nieistniejące związki, na przykład jest przekonana, że mężczyzna wykonujący zawód księgowego będzie cechował się nieśmiałością czy perfekcjonizmem, co oczywiście może mijać się z prawdą7. Powyższe dość wybiórczo potraktowane teorie od-

${ }^{4} \mathrm{~S}$. Byra, Mechanizmy kształtowania się stereotypów dotyczacych osób z niepetnosprawnościq, [w:] M. Chodkowska, S. Byra, Z. Kazanowski, D. Osik-Chudowolska, M. Parchomiuk, B. Szabała, Stereotypy niepetnosprawności. Między wykluczeniem a integracją, Wydawnictwo UMCS, Lublin 2010, s. 37-38; T. Mądrzycki, Wptyw postaw na rozumowanie, PWN, Warszawa 1974; Z. Chlewiński, 1992, za: M. Grabowska, Stereotypy płci we wczesnej dorostości, Wydawnictwo Uniwersytetu Kazimierza Wielkiego, Bydgoszcz 2007.

${ }^{5}$ Bartlet, 1932, za: C.N. Macrae, C. Stangor, M. Hewstone, Stereotypy i uprzedzenia, Gdańskie Wydawnictwo Psychologiczne, Gdańsk 2010, s. 17.

${ }^{6}$ E. Aronson, dz. cyt.; Weigl, 1999, za: S. Byra, dz. cyt.

${ }^{7}$ E. Aronson, dz. cyt., s. 137-138. 
noszą się do zestawu przekonań na temat danej zbiorowości ${ }^{8}$. Co zatem poprzedza pojawienie się dotąd opisanych mechanizmów?

Otóż zanim dojdzie do uruchomienia między innymi mechanizmu kategoryzacji w postrzeganiu, człowiek gromadzi określoną wiedzę nabytą $\mathrm{w}$ procesie socjalizacji. Pojawienie się stereotypów w świadomości jednostki bierze swoje źródło przede wszystkim $\mathrm{z}$ interakcji zachodzących w określonym kontekście kulturowym. Pierwotnym środowiskiem przekazywania dziecku preferowanych przez część społeczeństwa poglądów jest niewątpliwie rodzina. To właśnie w niej nieukształtowana mentalnie jednostka obserwuje wzorce zachowań najbliższych sobie osób, a w późniejszym czasie zaczyna je naśladować (modelować) tak, by zyskać akceptację otoczenia, a także uniknąć kar czy wyrazu dezaprobaty za ujawnienie społecznie niepożądanych działań. Wraz z rozszerzaniem się kręgu interakcji dziecko ulega wpływom innych czynników. Przejmuje wartości propagowane wśród grupy rówieśniczej czy zamieszczone w środkach masowego przekazu (o czym będzie mowa w dalszej części) ${ }^{9}$. Podkreślenia wymaga również fakt, że motywacja do posługiwania się stereotypowym myśleniem nie jest jednoznacznie zdeterminowana przez przestrzeń wychowawczą. Otóż znaczącą rolę odgrywać może sama osobowość jednostki - poziom (adekwatność) jej samooceny oraz skłonność do postaw konformistycznych czy autorytarnych ${ }^{10}$.

Dokonując swoistego podsumowania rozważań na temat stereotypów, należałoby przybliżyć znaczenie następujących pojęć: uprzedzenia, dyskryminacja $i$ samospetniające się proroctwo. Pierwsze z wymienionych dotyczy postaw czy „nastawienia wobec kogoś lub

8 C.N. Macrae, C. Stangor, M. Hewstone, dz. cyt.

${ }_{9}$ A.I. Brzezińska (red.), Psychologiczne portrety człowieka, Gdańskie Wydawnictwo Psychologiczne, Gdańsk 2005, s. 228; M. Grabowska, dz. cyt.; C.N. Macrae, C. Stangor, M. Hewstone, dz. cyt.; D.G. Myers, Psychologia społeczna, Zysk i S-ka, Poznań 2003.

${ }^{10}$ E. Aronson, dz. cyt.; C.N. Macrae, C. Stangor, M. Hewstone, dz. cyt.; Pettigrew, 1958, za: M. Grabowska, dz. cyt. 
czegoś, znajdujące odzwierciedlenie w przekonaniach, emocjach oraz zamierzonych zachowaniach"11. Z kolei drugi termin stanowi komponent behawioralny, a zatem odnosi się do odmiennego traktowania pojedynczych jednostek lub grup ${ }^{12}$, wynikającego ze schematów myślenia, które nierzadko przyczyniają się do usprawiedliwiania negatywnego postępowania. Uzasadnieniem dla praktyk dyskryminacyjnych jest dostrzeżenie piętna - właściwości odbiegającej od społecznie konstruowanej normy i deprecjonującej człowieka. Co najistotniejsze, niepożądana $\mathrm{w}$ danej zbiorowości cecha warunkuje specyfikę relacji pomiędzy osobą napiętnowaną a normalsem ${ }^{13}$. Przechodząc do meritum, identyfikacja stygmatu może doprowadzić następnie do dehumanizacji (odczłowieczenia) nosiciela, zapewniając jednocześnie postrzegającemu (normalsowi) komfort psychiczny dzięki temu, że znajduje argument irracjonalnie tłumaczący jego destrukcyjne zachowanie. Streszczone do tej pory zagadnienia z zakresu społecznego postrzegania w mniejszym stopniu odnosiły się do samych obiektów stereotypów. Warto zatem zastanowić się nad ewentualnymi konsekwencjami pojawiającymi się $\mathrm{u}$ jednostki funkcjonującej w obliczu generowania nieprzychylnych wobec niej postaw. Cennych informacji na ten temat dostarcza zjawisko samospełniającego się proroctwa. Otóż, stereotyp wyzwala konkretne oczekiwania wobec przedstawiciela zaliczonego do danej kategorii społecznej, w rezultacie specyfika relacji wymusza niekiedy od nosiciela piętna, by zachowywał się zgodnie $\mathrm{z}$ przewidywaniami interlokutora. Przykładem może być okoliczność infantylnego traktowania osoby z niepełnosprawnością, która potencjalnie może ulec "sugestiom” drugiej strony i przyjąć postawę uległości, mimo że taka reakcja wydaje się sprzeczna z jej osobowością.

11 D.G. Myers, dz. cyt., s. 152.

12 Warunkiem zaistnienia dyskryminacji jest to, by grupy lub jednostki z własnej woli oczekiwały równego traktowania (Allport, za: C.N. Macrae, C. Stangor, M. Hewstone, dz. cyt., s. 228).

${ }^{13}$ Normals to bardziej perspektywa aniżeli osoba, ponieważ nosiciel piętna może w niektórych sytuacjach sam stać się osobą dyskryminującą (choć z mniejszą częstotliwością niż osoba niewyróżniająca się z tłumu) (E. Goffman, dz. cyt.). 


\section{Wzory kulturowe a niepełnosprawność}

Nie bez powodu powyższa egzemplifikacja odnosi się do niepełnosprawności ${ }^{14}$. Łatwo bowiem wskazać materiały dotyczące stereotypowych treści postrzegania tej grupy społecznej. Po raz kolejny pozwolę sobie odnieść się do teorii piętna, która wydaje się kluczowa dla omawianej kwestii. Chcę zaznaczyć, że fakt występowania $\mathrm{u}$ jednostki nietypowego dla populacji atrybutu (natury cielesnej lub mentalnej) nie oznacza, że bezwzględnie zyskuje ona miano nosiciela piętna, ponieważ czynnikiem decydującym jest przede wszystkim dany zbiór promowanych wartości kulturowych. Zatem człowiek rozpoznawany jako geniusz zyska prawdopodobnie aprobatę otoczenia, dlatego że intelekt zajmuje wysoką pozycję $\mathrm{w}$ aksjologicznej hierarchii społeczeństwa ${ }^{15}$. Zdaniem Zygmunta Baumana, ponowoczesność nie znosi myślenia o chorobach, śmierci, wyraża sprzeciw wobec wszystkiego, co objawia się jako ludzka słabość16. Świat obserwowany przez współczesnego człowieka ma postać dwubiegunową, to znaczy istnieją w nim: dobro vs. zło, norma vs. patologia, piękno vs. brzydota, brakuje w nim natomiast przestrzeni na obecność elementów pośrednich, traktowanych jako pewne kontinuum ludzkiego życia ${ }^{17}$. Dochodzę do wniosku, że

${ }^{14} \mathrm{Na}$ potrzeby niniejszej publikacji przyjmuję definicję Europejskiego Forum Niepełnosprawności w Parlamencie Europejskim (październik 1994) głoszącą, iż "osobą niepełnosprawną jest jednostka w pełni swych praw, znajdująca się w sytuacji upośledzającej ją na skutek barier środowiskowych, ekonomicznych i społecznych, których z powodu występujących u niej uszkodzeń nie może przezwyciężać $\mathrm{w}$ taki sposób jak inni ludzie. Bariery te zbyt często są zwiększane przez deprecjonujące postawy ze strony społeczeństwa”; T. Gałkowski, Wokót definicji pojęcia „osoba niepełnosprawna" - doświadczenia europejskie, Problemy Rehabilitacji Społecznej i Zawodowej, <http://www.idn.org.pl/sonnszz/def_on.htm>, [dostęp: 20.10.2013].

${ }^{15}$ E. Goffman, dz. cyt.

${ }^{16}$ Bauman, 1998; za: E. Charzyńska, Mieć raka piersi i czuć się kobieta doświadczenia pacjentek o różnych orientacjach psychoseksualnych, [w:] K. Palus (red.), Płeć. Między ciałem, umystem i społeczeństwem, Wydawnictwo Naukowe Wydziału Nauk Społecznych, Poznań 2011.

${ }^{17}$ E. Charzyńska, dz. cyt., s. 149. 
w obliczu teraźniejszych trendów w społecznych dyskursach niepełnosprawność nadal stanowi niechętnie podejmowany temat. Pomimo licznych kampanii społecznych czy oferowanych programów rehabilitacji, mających na celu wyrównywanie szans, w zbiorowej świadomości naruszona sprawność wciąż jawi się jako życiowa tragedia. Przekonanie to ma swoje odzwierciedlenie w zestawie stereotypowych opinii oraz kreowanych w mediach wizerunkach tej grupy. Epitety określające „typową" osobę z ograniczoną sprawnością mają najczęściej charakter pejoratywny. Zazwyczaj postrzega się ją jako: „słabą, niewydolną fizycznie i umysłowo [...] niesamodzielną, nieproduktywną, nieporadną, nerwową, zdystansowaną, zależną od innych, złośliwą, drażliwą, wycofaną z życia społecznego [...], ubogą i niekompetentną. Nierzadko na całościową ocenę takiej jednostki wpływa zauważenie jednej, najistotniejszej dla obserwatora cechy"18.

Znaczącą rolę $\mathrm{w}$ aspekcie utrwalania schematów myślenia w omawianej kwestii odgrywają specjaliści, szczególnie w sytuacjach, gdy nie respektują potrzeby autonomii osoby, wobec której podejmują działania rehabilitacyjne. Pozbawiając pacjenta/klienta prawa do podejmowania samodzielnych decyzji (w kwestii ustalania życiowych priorytetów), można przyczynić się do wzmocnienia przekonania o zależności rzeczonej grupy ${ }^{19}$.

Dużą moc oddziaływania w procesie kształtowania społecznych postaw przypisuje się również mediom. Przekazy pojawiające się w kulturze masowej mogą kreować mity lub wzmacniać istniejące przekonania. Wystarczy obejrzeć kilka telewizyjnych reportaży, by zauważyć tendencję do przedstawiania grupy osób z niepełnosprawnością głównie w roli beneficjentów pomocy. Postrzega się ich jako ludzi godnych litości i generalnie niezdolnych do pełnego

18 Błeszyńska, 2001; Larkowa, 1987; Kawczyńska-Butrym, 1998; Mihilewicz, 2005; Malec, 2008; Ostrowska, Sikorska, 1996; Ostrowska, 1994, 1997; Żuraw, 1998, za: S. Byra, dz. cyt., s. 35.

${ }^{19}$ Finkelstein, 1980, za: C. Barnes, G. Mercer, Niepetnosprawność, Wydawnictwo Sic!, Warszawa 2008; A. Krause, Wspótczesne paradygmaty pedagogiki specjalnej, Oficyna Wydawnicza „Impuls”, Kraków 2010. 
uczestnictwa $w$ nurcie mainstreamu ${ }^{20}$. Promowanie tego typu obrazów działa na niekorzyść tych osób, ponieważ zwykle prezentuje ich jako jednostki doświadczające cierpienia lub wręcz przeciwnie herosów dzielnie pokonujących swoje słabości (przykładem może być historia Jana Meli). Na ile prezentowane wizerunki pokrywają się z rzeczywistością? Z nadzieją wyczekuję momentu, gdy obecność osoby $\mathrm{z}$ niepełnosprawnością $\mathrm{w}$ przestrzeni publicznej przestanie być czymś szokującym, a dysfunkcja będzie traktowana jak każda inna ludzka cecha. Zdaję sobie sprawę, że dokonanie się takich zmian wymaga czasu, a być może nawet kwalifikuje się do założeń utopijnych. Stanisław Kowalik twierdzi, że wyeliminowanie barier o społecznym charakterze wydaje się trudniejsze w porównaniu z pozbyciem się fizycznych przeszkód wymagających po prostu nakładów finansowych ${ }^{21}$.

W kontekście niepełnosprawności mówi się o różnych formach dyskryminacji. Mimo że polskie prawo ${ }^{22}$ uwzględnia ochronę interesów tej grupy, to w praktyce nadal dostrzega się szereg barier. Te przejawiają się $\mathrm{w}$ niedogodnościach lokomocyjnych $\mathrm{w}$ miejscach publicznych, trudnościach $\mathrm{w}$ zdobyciu solidnego wykształcenia i uzyskaniu zatrudnienia czy wreszcie w szkodliwych postawach uwarunkowanych społecznie ${ }^{23}$. Należy zauważyć, że wymienione problemy ulegają nasileniu wraz z wkroczeniem w okres dorosłości ${ }^{24}$.

${ }^{20}$ Mając świadomość, że zabiegi tego rodzaju są celowe i służą zachęceniu ludzi do wspierania najbardziej potrzebujących, zwracam jednak uwagę na to, by podkreślać różnorodność populacji osób z niepełnosprawnością.

21 S. Kowalik, Psychologia rehabilitacji, Wydawnictwo Akademickie i Profesjonalne, Warszawa 2007.

22 Por. Karta Praw Osób Niepełnosprawnych, <http:/ / www.niepelnosprawni. gov.pl/karta-praw-osob-niepelnosprawnych/>, [dostęp: 19.10.2013].

23 S. Kowalik, dz. cyt.; M. Szpunar, Życie z piętnem. Studia jako próba zdeprecjonowania stygmatu osoby niepetnosprawnej, "e-mentor” 2010, 2, s. 62-69; P. Todys, por. Sytuacja osób niepetnosprawnych na rynku pracy w Polsce w 2008 roku, Towarzystwo Edukacji Antydyskryminacyjnej, <http://www.niepelnosprawni.gov.pl>, [dostęp: 22.10.2013].

${ }^{24}$ K. Piotrowski uważa, że osoby z niepełnosprawnością mogą przejawiać problemy związane $\mathrm{z}$ realistycznym planowaniem swojej przyszłości, a napotykane 
Otóż specyfika dzieciństwa wiąże się z większą swobodą, nie narzucając w nadmiarze wymagań ze strony otoczenia. Bycie dzieckiem z niepełnosprawnością nie wzbudza bowiem takich ambiwalentnych emocji, jak w przypadku dorosłego dotkniętego dysfunkcją, który niejednokrotnie, z różnych przyczyn, napotyka na przeszkody w obszarze realizacji nowych zadań społecznych. Właściwe wypełnianie owych zadań może stać się źródłem osobistej satysfakcji, społecznej aprobaty czy gwarantem pomyślności na kolejnych etapach życia. Motywacją do podjęcia nowych wyzwań są takie czynniki, jak: somatyczne dojrzewanie (związane między innymi ze zwiększoną płodnością), nacisk kulturowy i indywidualne aspiracje lub/i wartości ${ }^{25}$. Robert J. Havighurst wyróżnia następujące zadania społeczne przypadające na okres wczesnej dorosłości:

1) wybór małżonka (życiowego partnera),

2) uczenie się współżycia z partnerem,

3) założenie własnej rodziny,

4) wychowanie dzieci,

5) prowadzenie domu,

6) rozpoczynanie pracy zawodowej,

7) podjęcie obowiązków obywatelskich,

8) znalezienie pokrewnej grupy społecznej26.

Biorąc pod uwagę problematykę niniejszej publikacji, nasuwa się nurtujące pytanie, mianowicie: W których obszarach funkcjonowania społecznego niepełnosprawność generuje najwięcej problemów? Zapoznając się z powyższym zestawieniem, szczególną uwagę zwraca to, że dominująca część zadań społecznych odnosi się do kwestii pełnienia ról związanych z płcią. Rozpatrując rozwój

bariery potencjalnie sprzyjają niższemu poczuciu samodzielności (K. Piotrowski, Wkraczanie w dorosłość. Tożsamość i poczucie dorosłości młodych osób z ograniczeniami sprawności, Wydawnictwo Naukowe Scholar, Warszawa 2010).

${ }^{25}$ B. Harwas-Napierała, Dorostość jako spetnienie, Wydawnictwo Libron, Kraków 2012, s. 32.

${ }^{26}$ E. Gurba, Wczesna dorostość, [w:] B. Harwas-Napierała, J. Trempała (red.), Psychologia rozwoju człowieka. Charakterystyka okresów życia człowieka, Wydawnictwo Naukowe PWN, Warszawa 2007, s. 204. 
człowieka w ciągu całego życia, uwzględniam trafność koncepcji wzajemnego oddziaływania na siebie trzech sfer - soma, psyche i polis ${ }^{27}$. Zaburzenie w którejkolwiek $\mathrm{z}$ nich może spowodować nieprawidłowości w innej. Swoistą analogię dostrzegam w seksualności człowieka, która pełni jednocześnie funkcję prokreacyjną, hedonistyczną i więziotwórczą. Stanowi również jeden z wielu wyznaczników dobrej kondycji fizycznej, psychicznej oraz ogólnej aktywności organizmu ${ }^{28}$. Obszaru płciowości nie należy ograniczać wyłącznie do intymnego zbliżenia fizycznego, bowiem pojęcie to ma dużo szerszy wymiar. Najoczywistszymi cechami odróżniającymi kobietę od mężczyzny są rozbieżności dotyczące chromosomów w komórkach, budowy i funkcji układu rozrodczego, a także regulacji metabolizmu dokonującego się za sprawą odmiennej gospodarki hormonalnej organizmu ${ }^{29}$. Ponadto istnieją przesłanki sugerujące, że mózgi - w zależności od danej płci - nie są identyczne pod względem lokalizacji rejonów odpowiadających za określone funkcje, zatem wykazują inne predyspozycje ${ }^{30}$.

\section{W kręgu wzorów męskości i kobiecości}

Powyższe odrębności stanowią odkrycie z punktu widzenia nauk ścisłych czy przyrodniczych. Patrząc jednak na to zagadnienie przez pryzmat nauk społecznych, dochodzi się do wniosku, że zdefiniowanie kobiecości vs. męskości wymaga odniesienia się do różnorodnych aspektów. Otóż stereotypowe myślenie oraz pojawiające

${ }^{27}$ Jest to tzw. triada Arystotelesa. Odnosi się kolejno do sfery biologicznej, psychicznej i społecznej ludzkiego funkcjonowania (A.I. Brzezińska, dz. cyt.).

${ }^{28}$ Halstead, Salhoot, 1978, za: D. Radomski, Ocena życia seksualnego osób z niepetnosprawnością fizyczną, [w:] M. Kościelska, B. Aouila (red.), Człowiek niepetnosprawny. Rodzina i praca, Wydawnictwo Akademii Bydgoskiej im. Kazimierza Wielkiego, Bydgoszcz 2004, s. 144.

29 Blaim, 1986; Imieliński, Dulko, 1988, za: M. Grabowska, dz. cyt.

30 Por. D. Jessel, A. Moir, Płeć mózgu, Państwowy Instytut Wydawniczy, Warszawa 2008. 
się za jego sprawą określone postawy i zachowania przenikają do wielu sfer ludzkiej egzystencji. Schematy, o których mowa na wstępie, mają również swoje odbicie w kwestii społecznej percepcji zestawu cech specyficznych dla wybranej płci. Już od najmłodszych lat dzieci zostają wychowawczo przygotowywane do bycia dziewczynką lub chłopcem. Stosowanie przez dorosłych systemu kar i nagród powoduje, że przejmują one „właściwy” dla nich zbiór zachowań i preferencji, jeśli chodzi o wybór zainteresowań, rodzaju zabaw czy chociażby koloru ubrań. Zdobywanie wiedzy na temat wyznaczników kobiecości i męskości sprawia, iż w przyszłości dorosła jednostka poddaje się społecznym wzorcom, respektując zarazem ład ustalony w danej zbiorowości31.

Monograficzne badania antropologiczne autorstwa Margaret Mead rzuciły nowe światło na precyzyjniejsze zdefiniowanie tego, czym jest płeć. Wyczerpujące obserwacje i analizy struktur życia trzech plemion zamieszkujących teren Nowej Gwinei uświadomiły, że pojęcie płci jest wytworem świadomości poszczególnych społeczności, a atrybuty określające „kobiecą kobietę” czy „męskiego mężczyznę" nie należą do uniwersalnych, ponieważ zależą od wytworzonej perspektywy społeczno-kulturowej. W związku z tym można wykluczyć całkowity determinizm biologiczny osobowości człowieka ${ }^{32}$.

Współcześnie, w dużej mierze, tłem dla formowania się tożsamości jednostki jest kultura masowa ${ }^{33}$. Jak zauważa Aneta Osta-

${ }^{31}$ A.I. Brzezińska, dz. cyt.; A. Buczkowski, Dwa różne światy, czyli jak socjalizuje się dziewczynkę i chtopca, [w:] J. Brach-Czaina (red.), Od kobiety do mężczyzny i z powrotem. Rozważania o ptci w kulturze, Trans Humana, Białystok 1997; E. Mandal, Podmiotowe $i$ interpersonalne konsekwencje stereotypów zwiąane z ptcia, Wydawnictwo Uniwersytetu Śląskiego, Katowice 2000.

32 E. Głażewska, Płeć $i$ antropologia, Wydawnictwo Adam Marszałek, Torun 2005.

${ }^{33}$ Zdaniem T. Szkudlarka i Z. Melosika tożsamość współczesnego człowieka nie jest mu dana raz na zawsze. Specyfika kontekstu kulturowego przyczynia się do niestałości tożsamości, podlegając zmianom uzależnionym od stanu „tu i teraz” czy aktualnego „pomysłu na siebie” (por. Z. Melosik, T. Szkudlarek, Kultura, tożsamość i edukacja. Migotanie znaczeń, Oficyna Wydawnicza „Impuls”, Kraków 1998). 
szewska, mass media przestały pełnić jedynie funkcję komunikacyjną czy rozrywkową, gdyż przejęły role tradycyjnych instytucji odpowiedzialnych za socjalizację, takich jak rodzina, szkoła czy Kościół. Panujące w kulturze masowej zjawisko konsumpcjonizmu, autokreacja w wirtualnej przestrzeni, a przede wszystkim koncentracja na cielesności w szczególny sposób oddziałują na styl życia/bycia jednostki. Ponadto stanowią niejako punkty odniesienia w kwestii udzielania odpowiedzi na pytania: Kim jestem? Jaki jestem? Także w obszarze płciowości ${ }^{34}$.

Tyrania ciała, a więc poddawanie się wszelkim zabiegom upiększającym, ma na celu dorównanie aktualnym trendom dyktującym, jak powinno się wyglądać, by zanadto nie odbiegać od estetycznych standardów, a tym samym zyskać akceptację otoczenia. Zdaniem Zbyszko Melosika, „kobiety pragną być piękne, aby stać się kobietami; z kolei mężczyźni poszukują piękna w kobietach"35. Nie chodzi tu bynajmniej o urok wewnętrzny, lecz wizerunek ciała, który najczęściej stanowi podstawowy wyznacznik atrakcyjności. Poczucie tożsamości płci żeńskiej jest zatem konstruowane głównie na podstawie oceny fizyczności - im kobieta ładniejsza w społecznej percepcji, tym prawdopodobnie będzie wyróżniać się wyższym poziomem samooceny i odwrotnie. Jednakże o postrzeganiu kobiecości nie decyduje całokształt, lecz poszczególne fragmenty ciała ${ }^{36}$ kulturowo kojarzone z erotyzmem (piersi, uda, usta, nogi itd.), co $\mathrm{w}$ pewnym sensie uzasadnia osobliwość lęku przed zachorowaniem na raka piersi i związanym z nim zabiegiem mastektomii ${ }^{37}$.

W literaturze można natknąć się na liczne publikacje odnoszące się do sfery płciowości osób z niepełnosprawnością. Dariusz Radomski wskazuje na konieczność zerwania z ich stereotypem asek-

${ }^{34}$ A. Ostaszewska, Popkulturowe ramy tożsamości. Media, kultura popularna, internet jako nowe środowisko kształtowania tożsamości, Ośrodek Rozwoju Edukacji, Warszawa 2012, <http:/ / www.ore.edu.pl>, [dostęp: 19.10.2013].

35 Z. Melosik, Tożsamość, ciało $i$ władza w kulturze instant, Oficyna Wydawnicza „Impuls”, Kraków 2010, s. 22.

36 Tamże.

37 Por. E. Charzyńska, dz. cyt. 
sualności, korzystając przy tym z siły perswazji, jaką daje działalność mass mediów. Współczesna kultura traktuje seks jako przywilej dostępny tylko dla wybranych (głównie zdrowych, sprawnych i atrakcyjnych) ${ }^{38}$. Zgodnie z tym stwierdzeniem widoczna dysfunkcjonalność organizmu może odgrywać rolę czynnika dyskwalifikującego lub lokującego jednostkę na niskiej pozycji w ustalonej hierarchii. Z dotychczasowych rozważań stopniowo wyłania się konkluzja prowokująca do postawienia pytania o społeczną pozycję kobiet $\mathrm{z}$ widocznym piętnem natury fizycznej. Czy rzeczywiście niepełnosprawność „podkopuje” korzenie kobiecości? Helen Meekoshy i Leanne Dowse twierdzą, że ta grupa żeńskiej populacji ma zdecydowanie mniejsze szanse na wyrażanie własnej kobiecości w codziennych sytuacjach. Podczas gdy feministki walczą o oswobodzenie się ze stereotypów płci, niepełnosprawne kobiety chciałyby wpisywać się w owe schematy, pozbywając się zarazem etykietki osoby aseksualnej, którą dodatkowo wzmacniają przekazy medialne ${ }^{39}$.

Zestawienie podjętych przeze mnie wątków miało na celu ukazanie podłoża teoretycznego, za sprawą którego otrzymałam impuls do zainteresowania się zagadnieniem poczucia kobiecości populacji osób z niepełnosprawnością ruchową. Mam świadomość, że zdefiniowanie niepełnosprawności zostało powierzchownie potraktowane chociażby ze względu na pominięcie szczegółowego opisu klasyfikacji rodzajów dysfunkcji. Podkreślenia wymaga fakt, że pojęcie niepełnosprawności, niezależnie od typu, ma przede wszystkim wymiar społeczny, a więc w dużym stopniu wynika z nieadekwatności organizacji życia czy, inaczej mówiąc, niedostosowania środowiska do specyficznych potrzeb konkretnej grupy odbiorców. Dostrzegam, że jedną z najbardziej niepokojących barier jest zjawisko stereotypizacji niosące z sobą szereg konsekwencji zauważalnych na poziomie interakcji czy $\mathrm{w}$ aspekcie obrazu własnego Ja. Dodatkowym czynnikiem stającym na przeszkodzie do społecznej

${ }^{38}$ M. Tepper, „Sexuality and Disability” 2000, Vol. 18, Issue 4, s. 283-290.

${ }^{39}$ Meekoshy, Dowse, 1997; Fine, Ash, 1998, za: C. Barnes, G. Mercer, dz. cyt. 
integracji jest znamienny dla kultury popularnej hedonistyczny system wartości. Wydaje się, że aktualnie sceptycznie podchodzi się do treści oscylujących wokół odmienności, słabości czy względnej brzydoty. Z autopsji wiem, że widoczność tak zwanego piętna może generować pojawienie się określonych problemów w obszarze relacji interpersonalnych. Zestaw stereotypów na temat niepełnosprawności oraz specyfika promowanego obecnie stylu życia tworzą swoisty krajobraz dla postrzegania pozycji kobiet, których wygląd i poziom sprawności odbiegają od powszechnie zdefiniowanej normy ${ }^{40}$.

\section{Projekt badań własnych}

$\mathrm{Na}$ podstawie analizy zaprezentowanej wiedzy teoretycznej zrodził się pomysł przeprowadzenia badań, których celem było określenie poczucia kobiecości w kontekście funkcjonowania $\mathrm{z}$ widoczną niepełnosprawnością ruchową w okresie wczesnej dorosłości ${ }^{41}$.

Proces badawczy miał charakter jakościowy w aspekcie gromadzenia i interpretacji danych, w dużej mierze opierał się również na strategii fenomenologicznej, kładąc nacisk na unikatowość narracji respondentek - ich subiektywny odbiór obserwowanej rzeczywistośi $^{42}$. Procedury badawcze zostały oparte na metodzie wywiadu (konkretnie jawnego i indywidualnego), którą Janusz Sztumski traktuje jako szczególnie przydatną w sytuacjach, kiedy celem dociekań naukowych staje się poznanie ludzkiej świadomości, czyli dotarcie na przykład do intymnych przeżyć respondentów. Należy

${ }^{40}$ Por. A. Ostrowska, J. Sikorska, Niepetnosprawność kobiet. Płeć jako dodatkowy czynnik marginalizujacy?, „Problemy Rehabilitacji Społecznej i Zawodowej” 1997, 1, s. 54-63.

${ }^{41}$ Badania stanowią część pracy magisterskiej pt. Stereotypizacja a poczucie kobiecości w kontekście widocznej niepetnosprawności ruchowej w okresie wczesnej dorostości, napisanej pod kierunkiem prof. dr hab. Iwony Chrzanowskiej.

$42 \mathrm{~J}$. Gnitecki, Elementy metodologii badań w pedagogice hermeneutycznej, Wydawnictwo Naukowe WSP, Zielona Góra 1996. 
zarazem podkreślić, że wspomniany autor wymienia niektóre cechy wywiadu tożsame $\mathrm{z}$ tymi, które pojawiają się u Mieczysława Łobockiego przy okazji opisu metody dialogowej. Otóż charakterystyczne dla ostatniej: otwartość wobec rozmówcy oraz umiejętność aktywnego słuchania, okazały się w tym przypadku elementami niezbędnymi w uzyskaniu autentycznych narracji ${ }^{43}$. Ponadto, w badaniach została użyta również pisemna ankieta (poprzedzająca wywiad), która posłużyła wstępnemu zebraniu informacji o grupie badawczej, uwzględniając następujące zmienne: wiek, wykształcenie, stopień niepełnosprawności, miejsce pochodzenia, wykształcenie rodziców, stan pierwotnej rodziny, aktywność zawodową, aktualne miejsce zamieszkania, przynależność do wspólnoty, posiadanie partnera oraz subiektywną ocenę sytuacji finansowej. Znajomość powyższych wskaźników miała na celu zapewnienie taktowności $\mathrm{i}$ indywidualnego podejścia do każdej z respondentek podczas zadawania pytań. Sam wywiad opierał się na kwestionariuszu o układzie półstandardowym tak, by optymalnie skoncentrować się na rozwinięciu wątków ważnych z punktu widzenia celu badawczego i jednocześnie uniknąć dygresji. W wywiadach wzięło udział dziesięć kobiet, których niepełnosprawność jest wyraźna (dwie z nich poruszają się na wózku inwalidzkim, dwie chodzą o kulach, reszta przemieszcza się samodzielnie). Innym równie ważnym kryterium doboru próbki badawczej, poza widoczną dysfunkcją, był wiek wskazujący na znajdowanie się w okresie wczesnej dorosłości (od 20 do 29 lat). Zdecydowana większość respondentek ma wyższe wykształcenie lub studiuje. Ograniczona objętość publikacji uniemożliwia mi zaprezentowanie całości wyników, zatem skoncentruję się na najważniejszych problemach pojawiających się w wywiadach, które, moim zdaniem, rzadko poruszane są w publicznej debacie.

W zestawie pytań/tematów zadanych respondentom można wyróżnić trzy obszary, mianowicie:

${ }^{43}$ M. Łobocki, Wprowadzenie do metodologii badań pedagogicznych, Oficyna Wydawnicza "Impuls”, Kraków 2007; J. Sztumski, Wstęp do technik i metod badań społecznych, Wydawnictwo Naukowe „Śląsk”, Katowice 2010. 
1) ocena relacji „moja niepełnosprawność a kontakty z innymi ludźmi",

2) ocena relacji „moja niepełnosprawność a dorosłość”,

3) ocena relacji „moja niepełnosprawność a poczucie kobiecości".

Widać, że układ treści kwestionariusza wywiadu miał na celu ukazanie możliwie szerokiego kontekstu funkcjonowania z ograniczoną sprawnością. Po kolei, jak wspomniałam, przedstawię najbardziej kluczowe aspekty, odwołując się do wymienionych obszarów.

\section{Bycie kobietą w narracjach kobiet z niepełnosprawnością ruchową w okresie wczesnej dorosłości}

Respondentki opisują społeczne tendencje odnoszące się do traktowania osób z niepełnosprawnością. Podają przykłady wskazujące na postawy wrogości, litości czy dystansu, ale oprócz tego przywołują także przypadki pozytywnych reakcji. Badane najczęściej doświadczają mało komfortowych sytuacji ze strony osób starszej generacji, mających zwyczaj wypytywania ich o przyczynę choroby. Poza tym nierzadko jednostki te niedyskretnie się przyglądają lub natrętnie oferują pomoc i religijne obrazki - dążąc generalnie do infantylizacji rozmówcy i przypisania mu roli cierpiętnika. Kobiety dodają, że mają potrzebę ciągłego udowadniania swojej zaradności i samodzielności w życiu, zwłaszcza w obliczu kreowania negatywnego wizerunku osób $z$ niepełnosprawnością $w$ mediach. Nieco lepiej w ocenie badanych wyglądają kontakty z młodszym pokoleniem, a zmiany zbiorowej świadomości zmierzają $w$ dobrym kierunku, ponieważ następuje stopniowe oswajanie ludzi z widokiem fizycznej odmienności. To z kolei oznacza, że osoby z niepełnosprawnością zaczynają coraz bardziej otwierać się na świat, zamiast wstydliwie skrywać się w domu.

Poza kontaktami z przypadkowo spotkanymi ludźmi respondentki odnosiły się również do relacji z rodziną, osobami z pra- 
cy/uczelni oraz z grupy towarzyskiej. Mówiąc w skrócie, badane czują się akceptowane, podkreślając zarazem, że początki bywają trudne, jednak długość trwania znajomości działa na ich korzyść, to znaczy umożliwia zmianę wyobrażenia o nich, osłabiając stereotyp. Zdaniem kobiet rodzina zapewnia im materialno-emocjonalne wsparcie, starając się jednocześnie stawiać im realne wymagania. Są jednak wyjątki wskazujące na to, że niepełnosprawność może mieć wpływ na relacje z najbliższymi. Przykładem może być pojawiająca się postawa nadopiekuńczości lub brak przyzwolenia na realizację $\mathrm{w}$ niektórych rolach społecznych (jedna $\mathrm{z}$ respondentek poczuła się skrzywdzona, kiedy rodzina źle zareagowała na wiadomość o jej ciąży, co zinterpretowała jako oznakę odebrania jej swobody w kwestii samodzielnego planowaniu swojej przyszłości). Jeśli chodzi o aspekt towarzyski, respondentki w większości przyjaźnią się z grupą mieszaną. Nie dokonują segregacji pod względem warunków zdrowotnych, choć $\mathrm{w}$ niektórych fragmentach wypowiedzi zaznaczają, że przebywanie z ludźmi z podobnymi problemami daje im konkretne korzyści - $\mathrm{w}$ postaci wzajemnego wsparcia czy nabierania dystansu wobec własnych ograniczeń (mowa między innymi o wspólnym żartowaniu z niepełnosprawności).

Badana grupa definiuje własne poczucie dorosłości, opierając się na różnych kryteriach. Uzupełniając zdanie: "Jestem dorosła, ponieważ...", wyraźna większość respondentek używa sformułowań odnoszących się do psychiczno-emocjonalnej dojrzałości przejawiającej się w: odpowiedzialności za siebie i innych, umiejętności podejmowania samodzielnych decyzji, zdolności planowania swojej przyszłości, ponoszeniu konsekwencji swoich czynów, dystansie do świata i przyjęciu czyjejś perspektywy patrzenia na pewne sprawy. Natomiast zdecydowanie mniejsza partia wypowiedzi dotyczy niezależności finansowej czy pełnienia ról społecznych charakteryzujących ten etap życia. Ponadto, niektóre z respondentek podkreślają, że nie wykazują silnej potrzeby utożsamiania się z dorosłością, ponieważ z racji swojego młodego wieku widzą możliwość zdobywania wykształcenia i swobodnego eksplorowania otaczającej ich rzeczywistości. Co najistotniejsze, zdania na temat wpływu niepeł- 
nosprawności na funkcjonowanie w dorosłości są podzielone. Część dochodzi do wniosku, że ta właściwość utrudnia bycie społecznie postrzeganą jako dorosła pomimo wewnętrznego poczucia, że zasługuje się na to miano. Z drugiej zaś strony pojawiają się opinie mówiące o tym, iż specyfika trudności związanych z dysfunkcją narządu ruchu powoduje, iż respondentki czują się bardziej dorosłe pod względem mentalnej dojrzałości. Otóż, interpretując ostatnią z opinii, można wnioskować: wybrane respondentki mają pozytywny autostereotyp własnej grupy, co może być czynnikiem wspierającym dla ich samooceny ${ }^{44}$. Przytoczone cytaty stanowią swoistą kwintesencję streszczonych wyników:

„Stereotypy związane z moją niepełnosprawnością utrudniają to wkroczenie w dorosłość. Słyszę nadal opinie innych ludzi z przeszłości: «Ty pewnie zawsze będziesz mieszkać z mamusią, będziesz zależna i nie ma opcji, że będziesz sama się utrzymywać i wychowywać dziecko. Oczywiście w teorii rodzina dała mi swobodę, ale chyba nawet nie zakładali, że ja będę kiedykolwiek uprawiać seks»".

„Niepełnosprawność utrudnia mi bycie postrzeganą w społeczeństwie jako dorosła, może ze względu na moje gabaryty, a może dlatego, że jestem na wózku, jestem niżej fizycznie od innych, to właśnie ludziom zdarza się, nawet nieświadomie, mówić do mnie jak do dziecka. Natomiast czy mi osobiście przeszkadza niepełnosprawność w dorosłym życiu? Z pewnością mogę powiedzieć, że nie”.

„Niepełnosprawność hartowała mnie od dzieciństwa, dlatego teraz, w dorosłości jest mi łatwiej”.

Przechodząc do przedstawienia wyników z zagadnienia poczucia kobiecości, omówię najpierw kwestię samej definicji tegoż pojęcia, gdyż moim zdaniem jest ona kluczowa dla dalszej interpretacji w powiązaniu z konsekwencjami niepełnosprawności. Otóż uzupełnienie zdania: „Być kobietą to...” zaskakuje swą różnorodnością

44 Por. S. Bedyńska, P. Rycielski, Kim jestem? Przeciwdziałanie stereotypizacji i stygmatyzacji osób z ograniczeniami sprawności, Wydawnictwo Naukowe Scholar, Warszawa 2010. 
- z narracji wyłaniają się dwie przeciwstawne kategorie. $\mathrm{Z}$ jednej strony respondentki identyfikują kobiecość z zewnętrznymi cechami czy rolami społecznymi, zauważalnymi przez otoczenie. Wśród nich znajdują się: wypełnianie obowiązków matki, gospodyni domowej, realizowanie się $\mathrm{w}$ charakterze życiowej partnerki, dbałość o wygląd tak, by wzbudzać zainteresowanie mężczyzn lub po prostu być estetyczną (przejawiające się w: pielęgnacji paznokci i cery, względnie ładnym ubiorze, goleniu nóg, makijażu, ładnej fryzurze, szczupłej sylwetce czy częstym uśmiechu).

$\mathrm{Z}$ drugiej strony ujawnia się postrzeganie kobiecości w zupełnie innym wymiarze, w którym wyznacznikami są właściwości mentalne, subiektywnie (niekiedy metafizyczne) odczuwane przez osobę. Należą do nich: poczucie akceptacji ze strony innych osób (w tym ojca i innych mężczyzn), życiowa mądrość, szacunek do siebie, skromność, niezależność, poczucie bycia atrakcyjną dla mężczyzny, łączenie w sobie subtelności (wrażliwości) i siły, umiejętność realizowania się $\mathrm{w}$ różnych obszarach życia i spełniania własnych marzeń, poczucie zadowolenia z siebie, posiadanie wewnętrznej, dobrej energii (bez przejawiania agresji), opiekuńczość, zdolność „ożywiania” świata, poczucie posiadania wewnętrznego piękna, poczucie dowartościowującej więzi z Bogiem.

Powyższe definicje są niejako punktem wyjścia do analizy wyników odnoszących się do strategicznego pytania problemowego, które brzmi następująco: „Jak respondentki postrzegają własną kobiecość, biorąc pod uwagę następstwa niepełnosprawności ruchowej, zauważalne przez nie tendencje kulturowe oraz dotychczasowe doświadczenia z płcią przeciwną?".

Po pierwsze, badane dostrzegają pewien dysonans w obszarze porównywania własnej osoby z zafałszowanym wizerunkiem kobiety w mediach. Wyrażają sprzeciw wobec traktowania całej żeńskiej populacji w kategorii obiektów seksualnych. Ponadto zwracają uwagę na fakt „faworyzowania” przez mężczyzn wybranych części ciała i niedocenianie pozostałych. W tym kontekście podają przykłady zachwycania się samymi nogami (zwłaszcza chodzenia na szpilkach), podczas gdy inne partie zostają pominięte. Zostaje także 
użyte sformułowanie: „kobieta od pasa w dół”, które oznacza, że ignoruje się niektóre walory kobiecej urody (na przykład atrakcyjną twarz), deprecjonując $\mathrm{w}$ ten sposób kobietę mającą problemy z poruszaniem się z gracją. Optymistycznie respondentki wskazują na medialne wizerunki kobiet przedstawiające je w lepszym świetle pokazujące ich osiągnięcia na różnych polach aktywności, choć niestety obok pozytywów nadal pojawiają się stereotypowe obrazy „kury domowej”. Ponadto pojawiają się wzmianki na temat coraz częstszej obecności kobiet $\mathrm{z}$ niepełnosprawnością $\mathrm{w}$ kulturze masowej, za przykład podaje się Monikę Kuszyńską (niepełnosprawną piosenkarkę, byłą wokalistkę zespołu Varius Manx) czy „Wybory Miss Polski na wózku”. W tym kontekście zostaje wygłoszona niezwykle trafna refleksja. Jedna z badanych kobiet zauważa, że kandydatki biorące udział w podobnych konkursach poza wózkiem inwalidzkim nie odbiegają znacząco od promowanych standardów wyglądu. W tym momencie zostaje zadane retoryczne pytanie: „Co z kobietami, które mają zdeformowane ciała, amputowane kończyny czy inne wyraźne defekty? Czy one również otrzymują szansę zaistnienia w przestrzeni publicznej?"45. Można dojść do wniosku, że tego typu inicjatywy służą jedynie swoistemu dopasowaniu niepełnosprawności do narzuconych kulturowo schematów odnoszących się do wyobrażenia na temat „prawdziwej” kobiety. Niestety nadal brakuje miejsca na dostrzeżenie potencjału tkwiącego w odmienności. Warunkiem zmiany obecnego stanu rzeczy byłoby dokonanie gruntownej redefinicji kobiecości.

W narracjach pojawiają się także fragmenty wskazujące na trudności $\mathrm{w}$ relacjach $\mathrm{z}$ płcią przeciwną, jednakże odnoszą się do przeszłości, a dokładniej do okresu adolescencji. Respondentki wspominają momenty, kiedy czuły się dyskryminowane $\mathrm{w}$ grupie rówieśniczej jako dziewczyny, chociażby w kwestii niedoświadczania "zalotów” tak, jak inne koleżanki. Zdawały sobie wówczas sprawę, że ich wygląd stanowił przyczynę mniejszej sympatii ze

45 Por. M. Świejkowski, Piękno w deformacji, <http://arteum.pl/aktualnosci/2010 _05_20_piekno_w_deformacji >, [dostęp: 25.10.2013]. 
strony chłopców. Patrząc z perspektywy czasu, respondentki zmieniły sposób postrzegania własnej osoby, upatrując siły swej kobiecości w takich zasobach, jak: mądrość, wrażliwość, wytrwałość w obszarze zdobywania wykształcenia i zawodowego rozwoju lub po prostu znając swoją podmiotową wartość46. Mniej natomiast koncentrują się wokół fizycznych cech, na które nie mają wpływu. Brak partnera życiowego (w ośmiu z dziesięciu przypadków) nie jest traktowany jako coś dyskredytującego, zdeterminowanego wyłącznie przez niepełnosprawność. Badane z tej grupy uważają, że dotąd nie natrafiły na odpowiednią osobę, a poza tym ich „ciężki charakter" utrudnia im wejście w intymną relację. Z drugiej zaś strony dwie respondentki będące $\mathrm{w}$ związku oświadczają, że czują się szczęśliwe i dowartościowane jako kobiety właśnie dzięki mężczyźnie znajdującym się u ich boku.

\section{Uwagi końcowe}

Reasumując, pozwolę sobie na nieco moralizatorskie stwierdzenie, że problem postrzegania kobiet $\mathrm{z}$ niepełnosprawnością leży wyłącznie po stronie społeczeństwa i, jak udowodniono, nie odbija się drastycznie na poczuciu tożsamości badanej grupy. Respondentki potrafią przeciwstawić się zbiorowym trendom, kładąc nacisk na samorealizację niezależnie od powszechnych opinii na ich temat. Można przypuszczać, że dominująca ich część ma poczucie bycia atrakcyjną, nie ograniczając się wyłącznie do wizualnych elementów. Ponadto wyniki niniejszego badania dostarczają motywacji do głębszego zastanowienia się nad specyfiką funkcjonowania naszego społeczeństwa. Myślę, że już na tym etapie niezbędna jest rekonstrukcja obecnego systemu wartości kulturowych, ponieważ tkwienie $\mathrm{w}$ iluzorycznym świecie plastikowego wynaturzenia bę-

${ }^{46}$ Więcej na ten temat pisze P. Skuza w publikacji pt. Poza wszelka sprawnością. O dwóch spojrzeniach na problem poczucia własnej wartości, [w:] K.D. Rzedzicka, A. Kobylańska (red.), Dorostość, niepetnosprawność, czas wspótczesny, Oficyna Wydawnicza „Impuls”, Kraków 2003. 
dzie stopniowo przyczyniać się do wyniszczenia tego, co naprawdę ważne. Jednostka określana mianem nowoczesnej może przejawiać trudności w moralnej ocenie rzeczywistości. Wystarczy zapoznać się z treściami zamieszczanymi na popularnym portalu społecznościowym, by zdiagnozować powolne zacieranie się granic pomiędzy tym, co normalne a tym, co nienormalne w dążeniu do stawania się człowiekiem przez duże "C".

\section{Bibliografia}

ARONSON E., Cztowiek - istota społeczna, Wyd. Nauk. PWN, Warszawa 2004.

BARNES C., MERCER G., Niepetnosprawność, Wyd. Sic!, Warszawa 2008.

BAUMAn Z., Ponowoczesność jako źródto cierpień, Wyd. Sic!, Warszawa 2011.

BEDYŃSKA S., RYCIELSKI P., Kim jestem? Przeciwdziatanie stereotypizacji i stygmatyzacji osób z ograniczeniami sprawności, Wyd. Nauk. Scholar, Warszawa 2010.

BRZEZIŃSKA A.I. (red.), Psychologiczne portrety cztowieka, Gdańskie Wydawnictwo Psychologiczne, Gdańsk 2005.

BUCZKOWSKI A., Dwa różne światy, czyli jak socjalizuje się dziewczynkę i chtopca, [w:] J. Brach-Czaina (red.), Od kobiety do mężczyzny i z powrotem. Rozważania o płci w kulturze, Trans Humana, Białystok 1997.

BYRA S., Mechanizmy kształtowania się stereotypów dotyczacych osób z niepetnosprawnościa, [w:] M. Chodkowska, S. Byra, Z. Kazanowski, D. Osik-Chudowolska, M. Parchomiuk, B. Szabała, Stereotypy niepetnosprawności. Między wykluczeniem a integracja, Wyd. UMCS, Lublin 2010.

CHARZYŃSKA E., Mieć raka piersi i czuć się kobieta - doświadczenia pacjentek o różnych orientacjach psychoseksualnych, [w:] K. Palus (red.), Płeć. Między ciałem, umysłem i społeczeństwem, Wyd. Nauk. Wydziału Nauk Społecznych, Poznań 2011.

GAŁKOWSKI T., Wokót definicji pojęcia "osoba niepełnosprawna" - doświadczenia europejskie, Problemy Rehabilitacji Społecznej i Zawodowej, <http://www.idn.org. pl/sonnszz/def_on.htm>, [dostęp: 20.10.2013].

GŁAŻEWSKA E., Płeć i antropologia, Wyd. Adam Marszałek, Toruń 2005.

GNITECKI J., Elementy metodologii badań w pedagogice hermeneutycznej, Wyd. Nauk. WSP, Zielona Góra 1996.

GofFMAN E., Piętno. Rozważania o zranionej tożsamości, Gdańskie Wydawnictwo Psychologiczne, Gdańsk 2007.

GRABOWSKA M., Stereotypy płci we wczesnej dorostości, Wyd. Uniwersytetu Kazimierza Wielkiego, Bydgoszcz 2007. 
Gurba E., Wczesna dorostość, [w:] B. Harwas-Napierała, J. Trempała (red.), Psychologia rozwoju człowieka. Charakterystyka okresów życia człowieka, Wyd. Nauk. PWN, Warszawa 2007.

HARWAS-NAPIERAŁA B., Dorostość jako spetnienie, Wyd. Libron, Kraków 2012.

<http://www.idn.org.pl/sonnszz/def_on.htm>, [dostęp: 22.10.2013].

Karta Praw Osób Niepełnosprawnych, <http://www.niepelnosprawni.gov.pl/kar ta-praw-osob-niepelnosprawnyc/>, [dostęp: 19.10.2013].

KOWALIK S., Psychologia rehabilitacji, Wyd. Akademickie i Profesjonalne, Warszawa 2007.

KRAUSE A., Wspótczesne paradygmaty pedagogiki specjalnej, Oficyna Wydawnicza „Impuls”, Kraków 2010.

ŁOBОСКі M., Wprowadzenie do metodologii badań pedagogicznych, Oficyna Wydawnicza „Impuls”, Kraków 2007.

MACRAe C.N., StANGOR C., HeWstone M., Stereotypy i uprzedzenia, Gdańskie Wydawnictwo Psychologiczne, Gdańsk 2010.

MANDAL E., Podmiotowe $i$ interpersonalne konsekwencje stereotypów związane z ptcia, Wyd. Uniwersytetu Śląskiego, Katowice 2000.

MĄDRZYCKI T., Wptyw postaw na rozumowanie, PWN, Warszawa 1974.

MELOSIK Z., Tożsamość, ciało i władza w kulturze instant, Oficyna Wydawnicza „Impuls", Kraków 2010.

MELOSIK Z., SZKUDLAREK T., Kultura, tożsamość i edukacja. Migotanie znaczeń, Oficyna Wydawnicza „Impuls”, Kraków 1998.

MOIR A., Jessel D., Płeć mózgu, Państwowy Instytut Wydawniczy, Warszawa 2008.

MYers D.G., Psychologia społeczna, Zysk i S-ka, Poznań 2003.

OSTASZEWSKA A., Popkulturowe ramy tożsamości. Media, kultura popularna, internet jako nowe środowisko ksztattowania tożsamości, Ośrodek Rozwoju Edukacji, Warszawa 2012, <http:/ / www.ore.edu.pl>, [dostęp: 19.10.2013].

OSTROWSKA A., SIKORSKA J., Niepetnosprawność kobiet. Płeć jako dodatkowy czynnik marginalizujący?, „Problemy Rehabilitacji Społecznej i Zawodowej” 1997, 1, s. 54-63.

PiOTROWSKI K., Wkraczanie w dorosłość. Tożsamość i poczucie dorosłości młodych osób z ograniczeniami sprawności, Wyd. Nauk. Scholar, Warszawa 2010.

RADOMSKI D., Ocena życia seksualnego osób z niepetnosprawnościa fizyczna, [w:] M. Kościelska, B. Aouila (red.), Człowiek niepetnosprawny. Rodzina i praca, Wyd. Akademii Bydgoskiej im. Kazimierza Wielkiego, Bydgoszcz 2004.

SKUZA P., Poza wszelka sprawnością. O dwóch spojrzeniach na problem poczucia własnej wartości, [w:] K.D. Rzedzicka, A. Kobylańska (red.), Dorosłość, niepetnosprawność, czas wspótczesny, Oficyna Wydawnicza „Impuls”, Kraków 2003.

SZPUNAR M., Życie z piętnem. Studia jako próba zdeprecjonowania stygmatu osoby niepetnosprawnej, „e-mentor" 2010, 2, s. 62-69.

SZTUMSKI J., Wstęp do technik i metod badań społecznych, Wyd. Nauk. „Śląsk”, Katowice 2010 . 
ŚWIEJKOWSKI M., Piękno w deformacji, <http://arteum.pl/aktualnosci/2010_05_20_ piekno_w_deformacji>, [dostęp: 25.10.2013].

TEPPER M., „Sexuality and Disability” 2000, Vol. 18, Issue 4, s. 283-290.

TODYS P., Przejawy dyskryminacji osób z niepetnosprawnościa ruchowa, <http:/ / www. tea.org.pl/userfiles/file/Seminaria/Niepelnosprawnosc_\%20ruchowa_PTodys _TEA.pdf>, [dostęp: 22.10.2013]. 